\title{
A Comparative Study of Education Exemptions to Copyright in the United States and Europe
}

\author{
By Robert J. Congleton ${ }^{*}$ \\ Sharon Q. Yang ${ }^{\dagger}$
}

This paper is a comparative study of copyright law and how it has been adapted by the United States, the European Union (EU), and selected European nations, including Greece, to address the needs of higher education in the digital age. This qualitative study will focus on how each nation has selected and implemented copyright exceptions for educational use of digital materials in colleges and universities. Pertinent international agreements, legal codes, and philosophical differences between the approaches taken by the United States and Europe will be described. The paper will also propose suggestions for creating more standardised access to educational resources.

Keywords: copyright; fair use; three-step-test; United States copyright law; European copyright law

\section{Introduction}

Copyright is designed to provide the creator of an intellectual property with legal protection of their exclusive rights to use and profit from their creations. Copyright laws also recognise that society needs to be able to access the created works in ways that require exemptions to those exclusive rights, such as educational uses. The rise of the digital age has provided new ways to publish and access copyrighted material, including cross border access to educational resources that challenges the creator/society balance incorporated in existing copyright law. The international community has been slow to address these issues, with differing cultural views leading to differing interpretations of international agreements, resulting in differing limits placed on the free use of copyrighted digital works for educational needs.

Historically, educational exemptions to copyright laws have been a part of every major intellectual property treaty since the 1886 Berne Convention for the Protection of Literary and Artistic Rights. The Berne Convention, created and signed by the leading nations of Europe, began the ongoing process of coordinating copyright law and educational exceptions between nations. Over the years, the Convention has been revised several times to meet the changing needs of copyright. In 1967, Article 10 was revised to include what is now called the three-step-test, the basis for most European copyright exemptions, including education. The Convention was last revised in 1979. Since 1970 the

\footnotetext{
* Associate Professor-Librarian-Archivist, Rider University, Lawrenceville, New Jersey, USA.

${ }^{\dagger}$ Professor-Librarian, Rider University, Lawrenceville, New Jersey, USA.
} 
World Intellectual Property Organization (WIPO) has been the primary entity responsible for revising international copyright agreements. Its efforts have produced the 1996 World Intellectual Property Organization Copyright Treaty (WIPOCT), the 1996 World Intellectual Property Organization Performances and Phonograms Treaty (WIPOPPT), the 2000 Agreement on Trade Related Aspects of Intellectual Property Rights (TRIPS), and the 2012 Beijing Treaty on Audio-visual Performances. The 1996 copyright treaty revised the language of Article 10 and has become the basic language for the three-step-test used by most treaty members: (1) certain special cases that (2) do not conflict with a normal exploitation of the work and (3) do not unreasonably prejudice the legitimate interests of the author. ${ }^{1}$

Early international treaties primarily addressed analogue works as use of the internet and digitised works did not begin until the early 1990s. The 1996 WIPO treaties were the first to begin addressing digital media, clarifying that reproduction rights, exceptions regarding computer programs, performances, and recordings in all modes or formats were covered within the articles of the Berne Convention. It also extended the three-step-test to the evolving digital network environment. While specific sections of each treaty can be extended to address some of those issues, too many concerns remain unresolved. None of the treaties specifically addressed whether digital materials were reproductions, rather than original creations, and thereby not covered by educational exemptions. Nor had the treaties anticipated and dealt with the growing use of digital materials in higher education, their use in classrooms, availability on learning management systems, or use in distance learning/online courses accessible via electronic reserves or other means in an academic library.

As more educational material is produced in a digital format, ownership of the material becomes an issue. Ownership has been an important factor in enabling educational exceptions for the use of copyright material in traditional classrooms, borrowing library books, and loaning material to other libraries via interlibrary loan. With digital material, licensing rather than ownership is rapidly become the preferred way publishers and other copyright holders allow access to works. Under licensing, access can be more controlled, allowing publishers to restrict access or adopt more open source approach to digital works. Such restrictions can limit the availability of that material for either face-to-face or distance learning classrooms. Licensing also affects the availability of the material via interlibrary loan, or restricts the number of simultaneous users or the number of times material can be used in a year. Since the material is no longer owned by a teacher, student or library, it may not be available for future consultation or use. This has already occurred with the rolling access to scholarly digital periodicals produced by major publishers and will be an important issue as use of eBooks increases.

Each international treaty has left it to its members to choose what exemptions to include in national legal codes. This has created a harmonised approach to copyright and education exemptions, with different exemptions being approved in each nation. Since 1996 the United States, the European

\footnotetext{
${ }^{1}$ WIPO Copyright Treaty, 1996, Article 10.
} 
Union, and individual nations have made attempts to address the continuing evolution of digital resources and copyright. The United States has relied on its Digital Millennium Copyright Act of 1998 and the Technology, Education and Copyright Harmonization (TEACH) Act of 2002 to address the growing copyright issues of the digital age. It also continues to rely on its notion of Fair Use, codified in 1976, to address education exceptions.

The European Union has issued three directives to harmonise national approaches to copyright and meeting treaty requirements. The 2001 Directive or European Union Copyright Directive (EUCD), addressed the nature of intellectual property rights. The Directive of 2004 addressed the enforcement of such rights, and the Directive of 2009 concerned legal protection for computer programs. Each included educational exceptions, but still allowed each member nation latitude in codifying their responses to the directive. These Directives are the basis for how each EU nation has approached copyright issues regarding digital material.

This paper will look at how the United States and three European nations have addressed education exceptions to their copyright law. The European nations have been selected for their differing legal traditions and EU membership. They include a Common Law nation (the United Kingdom) and two Civil Law nations (France and Greece) to compare the various ways culture and international participation have affected their approaches to education and copyright. The European nations are then compared to the approach and legislation used by the United States to address education exemptions. The authors will conclude by offering suggestions for better harmonizing the varied approaches to create greater consistency in allowing educational use of copyrighted material.

The authors did a similar comparison of copyright exemptions in $2011 .^{2}$ Since then, each of the three European countries reviewed in the current paper have revised their copyright codes, but only the United Kingdom's revisions include specific exemptions for using digital material in educational institutions.

\section{Copyright in the United States}

All education exceptions in the United States rest on the abstract concept of "fair use." Though the concept was first presented in an 1841 Supreme Court decision ${ }^{3}$, it was not codified into law until the Copyright Act of 1976, which dramatically revised United States copyright law. The revision was a major step by the United States to join the international community's attempts to harmonise approaches to intellectual property rights. Even so, it was not until 1988, following additional revisions to its copyright law, that the United States was declared eligible to sign the Berne Convention. Since 1988, The United States has been a member of all major international treaties regarding

\footnotetext{
${ }^{2}$ Congleton and Yang (2011).

${ }^{3}$ Folsom v. Marsh, 9 F. Cas. 342, No. 4,901 (C.C.D. Mass. 1841)
} 
copyright, even though the relationship of fair use to the three-step-test found in those agreements is unsettled.

It is fair use rather than the three-step-test, which is the foundation for all exemptions to copyright in the United States. It is used to justify a host of limitations to the exclusive rights of copyright owners, including criticism, comment, news reporting, teaching, scholarship, and research. By meeting the conditions of fair use, educators can freely reproduce and distribute copyrighted materials without the need to obtain permission from the copyright holder or pay a fee for such use.

The Copyright Act of 1976 codified four broad criteria as factors determining whether a use of copyrighted material is justified under fair use:

1. The purpose and character of the use, including whether such use is of a commercial nature or is for nonprofit educational purposes;

2. The nature of the copyrighted work;

3. The amount and substantiality of the portion used in relation to the copyrighted work as a whole;

4. The effect of the use upon the potential market for or value of the copyrighted work.

As a common law nation, the United States has left it to its courts to decide on a case by case basis whether a use qualifies as "Fair Use." While this has produced numerous court rulings about what is considered the fair use of copyrighted works, only a handful of those rulings directly addressed use in educational institutions. In one case, courts determined that fair use did not permit copyrighted material to be collected by educators and produced as anthologies or packets to be used in classrooms. ${ }^{4}$ Another case determined that the portion or excerpt of a work used in a classroom or placed on reserve in libraries for students to use and copy cannot be limited to a percentage or number of pages relative to the work as a whole. The substantiality of that portion must be determined on a case by case basis. ${ }^{5}$

In 1998, the United States passed the Digital Millennium Copyright Act of 1998 to bring the United States into conformity with the 1996 WIPO Copyright Treaty and the WIPO Performances and Phonograms Treaty provisions addressing illegal circumvention of digital rights management systems found on DVDs.

The Technology, Education, and Copyright Harmonization Act of 2002 (TEACH Act) amended the Copyright Act of 1976 to address distance education issues arising from the Digital Millennium Copyright Act. Under the TEACH Act, online instruction falls under fair use provided copyright policy is posted on the web, a copyright notice is attached to class materials, and measures are taken to restrict the use of online material to the registered students for the duration of the class. The Act also detailed the responsibilities

\footnotetext{
${ }^{4}$ Basic Books, Inc. v. Kinko's Graphics Corp.

${ }^{5}$ Cambridge University Press v. Patton.,
} 
of faculty, institution, and IT department when using copyrighted materials in online classes. ${ }^{6}$

Apart from fair use, the United States copyright code allows educators in nonprofit educational institutes to show a performance, motion picture, or other audiovisual work as part of classroom teaching activities in face-to-face and distance learning classes provided access to that performance is limited to the students enrolled in the specific course. For digital transmissions of the work, access is permitted only for the duration of the class. A nondramatic literary or musical work can be performed for the public provided the performance is not transmitted, and either there is no charge for admission or the admission charge is used exclusively for educational, religious, or charitable purposes.

In 2013 the U.S. Congress started a massive review process of court cases regarding fair use and other copyright issues. The review is part of the ongoing effort to develop a more comprehensive copyright law suited for the digital age. As of June 2016, many public hearings, but no legislation has been proposed. The review process has the potential to rework the balance between the copyright holder and the needs of society.

\section{Copyright in Europe}

In Europe, the three-step-test is the basis for determining exemptions to copyright law. It had its origins in the 1886 Berne Convention's statute regarding limits on reproduction rights. Those rights have been debated and revised in subsequent copyright treaties until a compromise was worked out in the 1967 revisions to the Berne Convention in which the concept of the threestep-test was adopted rather than an elaborate list of specific exemptions. As presented in the 1996 WTO Copyright Treaty, the three-step-test confines copyright limitations or exceptions to (1) certain special cases that: (2) do not conflict with a normal exploitation of the work, and (3) do not unreasonably prejudice the legitimate interests of the author. It was left to the signing nations to determine and provide those limitations as outlined in the Berne Convention. To meet the "special cases" requirement, European countries' legal codes include multiple sections detailing specific categories and cases qualifying for copyright exemption, or one section listing all such cases.

Another concept dealing with limitations on copyright is "Fair Dealing" which dates back to the early $18^{\text {th }}$ century. Fair dealing is found primarily in the copyright laws of the United Kingdom and other Commonwealth nations. It is a vague concept that is used to broaden the three-step-test in most common law nations. Fair dealing relates to the economic impact use of the work has on the copyright owner, and whether the amount of the work used is reasonable and appropriate ${ }^{7}$. Civil law countries, such as France, rely more strongly on the three-step criteria. France places greater emphasis on the "moral rights" of the author, and tilts its copyright balance in favour of the copyright holder. For

\footnotetext{
${ }^{6}$ Copyright Law of the United States. Title 17, section 110(2) and section 112(f).

${ }^{7}$ Fair Dealing Guidance - Exception to Copyright, 18 Nov. 2014.
} 
France, education exemptions are limited, and educators must rely more often upon licensing rather than exemptions to use print and digital works in their classrooms. Greece focuses on the moral rights of the author, but allows educational exemptions aligned with fair practice, the Greek version of fair dealing. These different philosophies regarding education exceptions exemplify the diversity among European countries regarding the balance between the rights of the author and the needs of society. ${ }^{8}$

Recognizing the need to harmonise its members' approaches to copyright, the European Union has issued several Directives designed to enforce the various treaties. The 2001 European Union Copyright Directive (EUCD), addressed the rights of reproduction and communication to the public and placed no limit on either the extent or nature of a work being used for noncommercial educational purposes in line with the three-step test. The Directive is broad enough to be applied to both face-to-face and distance learning classrooms. Directives issued in 2004, 2006, 2009, 2011 and 2014 addressed issues concerning the enforcement of intellectual property rights, legal protection for computer programs, and licensing of rights in musical works for online use. Like the international treaties, the Directives permit national legislation to provide for limitations of an author's copyright that meet the three-step-test requirements.

The EUCD exception list exemplifies the European approach to copyright, where the moral right of the author stands as the centre of copyright policy and limitations to those rights are specifically listed. This perspective empowers legislators with a moral obligation to safeguard rights in a broad fashion that allows authors the opportunity to profit from the use of their creation while barring others from exploiting these creations. Like the Berne Convention, and WTO treaties, the EUCD permitted EU members to adapt copyright exceptions into their national laws in accordance with their own national norms and traditions.

Significantly, while many of the provisions in each Directive can be applied to digital material, no Directive has explicitly addressed the many problems confronting educational institutions regarding use of data streaming technology or web-based material.

As part of their EU commitments, member educational institutions have licensing and collecting society obligations that often trump exemptions. Based on our review of European copyright laws, France mostly relies on licensing obligations for allowing educational institutions to use copyrighted material, rather than specific exemptions. ${ }^{9}$

The focus of this section will be on how the United Kingdom, France and Greece have addressed specific areas of education in their use of copyright exemptions and how such exemptions have addressed the educational issues of the digital age.

\footnotetext{
${ }^{8}$ See Cohen (2007) 1192-1197; Geller (2000) 256-263; Xalabarder (2009) 34-57.

${ }^{9}$ See Hilty and Nerisson (2012) 355-392 and Xalabarder (2004).
} 


\section{Comparison of European Countries' Copyright - Education Exemptions}

\section{Illustration/Reproduction for Instruction}

Copyright exemptions for education in the United Kingdom were revised in 2014 and broadened to address teaching in the digital age. Using a work for illustration in instruction is considered fair dealing provided such use is for a non-commercial purpose, done by a person giving or receiving instruction or examinations, and accompanied by sufficient acknowledgement. ${ }^{10}$ The revised code restricts the instructional use to not more than $5 \%$ of a work in a single year but excludes performances and artistic works from this exemption. ${ }^{11} \mathrm{~A}$ recording or copies of a full broadcast can be used for non-commercial instructional purposes, but proposals allowing exemptions for using extracts of performances and artistic works did not make the final version of the amended code. $^{12}$ The 2014 revisions address educational needs of the digital age by allowing one copy of exempted instructional material to be communicated via electronic systems such as smart boards and teaching management systems provided the material can be accessed only by the establishment's pupils and staff. ${ }^{13}$ Under these provisions, distance learning classrooms can also make use of the works. However, none of these exemptions are permitted if a license authorizing the acts is available. In that case, a licensing fee must be paid to the appropriate agency. ${ }^{14}$

France revised its intellectual property legal code in 2016, but did not change its copyright exemptions for education. French law permits the reproduction of extracts from copyrighted works, including digital editions, for either face-to-face or online education purposes provided such use does not entail commercial exploitation of the work and compensation for such reproduction is given to a collecting society. ${ }^{15}$

In Greece, the copyright code was amended in 2014, but the revisions did not affect the education exemptions permitted. Reproduction of articles from newspapers or periodicals, short extracts of a work, or lawfully published works of fine art are permitted for teaching or examination purposes at an educational establishment. Such copying must be in line with the 3-step criteria. Greek law does not explicitly limit such exceptions to print reproduction and therefore may allow digital or online reproduction for use in online distance learning. ${ }^{16}$

\footnotetext{
${ }^{10} 2014$ No. 2356 Copyright Rights in Performances, Article 32 section 1.

112014 No. 2356 Copyright Rights in Performances, Article 36, section 5.

122014 No. 2356 Copyright Rights in Performances, Article 36, section 6 and 6ZA.

${ }^{13} 2014$ No. 2356 Copyright Rights in Performances, Article 36, section 2 \& 3.

${ }^{14} 2014$ No. 2356 Copyright Rights in Performances, Article 36, section 6.

${ }^{15}$ Code de la propriété intellectuelle (version consolidée au 25 avril 2016). France: Intellectual Property Code (consolidated to April 25, 2016). World Intellectual Property Organization (WIPO). Article L122-5-3e.

${ }^{16}$ Greece - Law No. 2121/1993, Article 21.
} 


\section{Compilations and Anthologies}

The United Kingdom allows short passages from a published literary or dramatic work in a compilation intended for use in educational establishments provided it does not include more than two excerpts from copyright works by the same author published by the same publisher over a period of five years, and the work itself was not intended for use in educational establishments. The anthology must consist mainly of non-copyrighted material and does not limit such material to print, making it available for use in online classrooms or on learning management systems. ${ }^{17}$

France does not allow compilations unless licensed and compensation is paid to a collection society. ${ }^{18}$

Greece allows the inclusion of copyright material in textbooks approved by the Ministry of National Education and Religions without the consent of the authors and without payment. The material must consist of only a small portion of the total output of each writer. After the death of the author, his work can be reproduced in anthologies without the consent of the Ministry. All of this is permitted as long as there is no conflict with the normal exploitation of the work from which the texts are taken. The exemption refers to printed textbooks and is not applicable to online course material. ${ }^{19}$

\section{Performances}

The United Kingdom permits the performance of a literary, dramatic, or musical work performed before and limited to an audience consisting of teachers, students, and other persons directly connected with the activities of the establishment. The performance must not be for the general public. A parent is not considered a person directly connected with the activities of the establishment and must be excluded from the audience unless they meet the other requirements. ${ }^{20}$ These performances can be recorded and communicated via electronic means that limit access to students and staff of the institution. ${ }^{21}$

In France performances for purpose of education requires compensation to be paid to a collection society. ${ }^{22}$

Greece allows a public performance or presentation of a work without an author's consent of the author or fee, provided it is done as a staff and student activity at an educational establishment, and the audience is composed exclusively of the parents of the pupils or students, persons responsible for the

\footnotetext{
172014 No. 2356 Copyright Rights in Performances, Article 33.

18 "Code de la propriété intellectuelle (version consolidée au 25 Avril 2016)." France: Intellectual Property Code (consolidated to April 25, 2016). World Intellectual Property Organization (WIPO). Article L122-5-3e.

${ }^{19}$ Greece - Law No. 2121/1993, Article 20.

202014 No. 2356 Copyright Rights in Performances, Article 34.

${ }^{21} 2014$ No. 2356 Copyright Rights in Performances, Article 36.

22 "Code de la propriété intellectuelle (version consolidée au 25 avril 2016)." France: Intellectual Property Code (consolidated to April 25, 2016). World Intellectual Property Organization (WIPO). Article L122-5-3e.
} 
care of the pupils or students, or persons directly involved in the activities of the establishment. ${ }^{23}$

\section{Quotations}

In the United Kingdom's 2014 revisions copyrighted material can be quoted provided that the work has been made available to the public, the use of the quotation is fair dealing with the work, the extent of the quotation is no more than is needed for the specific purpose of use, and the quotation is accompanied by a sufficient acknowledgement. ${ }^{24}$

France permits quotations for analyses and short quotations warranted by the critical, polemical, pedagogical, scientific or nature of information of the work in which they are used. ${ }^{25}$

Greece permits quotations of short extracts of a lawfully published work in support for argument and criticism. Use of the quotation must be compatible with fair practice and the extent of the extracts must not exceed what is justified for that support. In addition, the source of the quotation must be provided, including the names of the author and of the publisher. ${ }^{26}$

\section{Streaming Video or Audio}

The United Kingdom excludes performances and artistic works from its exemptions for education. Therefore, any streaming of such works or making the full versions available for online access by students whether in a face-toface or online class requires a license.

Neither France nor Greece list the streaming of video or audio as educational exemptions.

\section{Comparison - Copyright Education Exemptions in the United States and Europe}

Like the Berne Convention, and WTO treaties, the EUCD permitted EU members to adapt copyright exceptions into their national laws in accordance with their own national norms and traditions. Most EU members list specific exemptions; the United Kingdom offers detailed descriptions, while France and Greece use more abbreviated general ones. This sets EU nations apart from the American approach which uses broad principles or guidelines such as "fair use" to outline general criteria limiting copyright.

\footnotetext{
${ }^{23}$ Greece - Law No. 2121/1993, Article 27.

${ }^{24} 2014$ No. 2356 Copyright Rights in Performances, Article 30, section 1ZA.

${ }^{25}$ Code de la propriété intellectuelle (version consolidée au 25 avril 2016). France: Intellectual Property Code (consolidated to April 25, 2016). World Intellectual Property Organization (WIPO). Article L122-5-3e.

${ }^{26}$ Greece - Law No. 2121/1993, Article 19.
} 
Fair Use, Fair Dealing, and the Three-step-test

Comparisons between the United States and European limitations regarding copyright protection must begin with addressing the differences between the concepts fair use, fair dealing, and the three-step-test. These concepts are the basis for all limits to copyright for each country compared in this paper. Of the three concepts, only aspects of fair dealing (fair practice) and the three-step-test have been part of major international treaties. However, the United States' notion of fair use has been growing in influence as nations adapt copyright to the digital age. The distinctions between the three concepts reflect the different cultural attitudes underlying common law and civil law views of copyright.

Common law nations such as the United States and the United Kingdom tend to view copyright as a means of improving society by encouraging intellectual endeavours. Copyright protection is an incentive for such activities, but that protection is limited in scope based on how the copyrighted work is used. Common law nations determine those limits through a case-by-case review in courts of law. The concepts of fair use and fair dealing reflect this cultural attitude.

In contrast, copyright protection in civil law countries, such as France and Greece, view the moral rights of the author as fundamental and safeguard those rights in legal codes that strongly recognises an author's exploitation rights, while narrowly defining and restricting exceptions. In these systems, the threestep-test is strictly interpreted.

The concepts of fair use and fair dealing date back to the mid- $19^{\text {th }}$ and early $18^{\text {th }}$ centuries respectively, far longer histories than the three-step-test. While they have evolved from a common tradition, the two concepts are quite different. Fair dealing has no statutory definition. It typically refers to two factors related to the use of a copyrighted work: the impact such use has on the work's economic value for the copyright owner, and whether the amount of the work used is reasonable and appropriate related. These two factors are narrower than the four criteria codified under fair use which includes consideration of the purpose and character of the use as well as the nature of the copyrighted work, in addition to economic considerations and the portion of the work used. The additional criteria enable a broader array of exemptions to fall under the concept of fair use than fair dealing.

As encoded in many European national copyright laws, the three-step test limits exemptions far more than either fair use or fair dealing. Many European nations have adopted a narrow list of "special cases" qualifying for exception status, as illustrated in this paper's section comparing the education exemptions of the United Kingdom, France, and Greece. Such specificity is not part of the underlying principles of fair use, though parallels can be found between fair use's first two factors concerning the purpose and character of use, and the nature of the work with the "special cases" criteria of the three-step-case. In addition, fair use's third and fourth factors concerning the amount of the work used and the effect on the potential market seem to match the three-step-test's 
criteria concerning normal exploitation and prejudice to legitimate interests of the author. Yet fair use has always permitted a wider range of educational exemptions to copyright than the three-step-test.

\section{General Education Exemptions Comparison}

The United States' concept of fair use generally allows educators free access to more copyrighted material than the European concepts of fair dealing and the three-step-test. Under fair use, the United States allows the use of copyrighted print and digitised material, and quotations or excerpts to be used in both face-to-face and distance learning classrooms but cannot include them in compilations distributed to students. The United Kingdom, through its use of fair dealing and the three-step-test, has similar allowances, but restricts the amount of a work that can be used. France relies on licensing to use those works, while Greece permits using only excerpts of printed works and no compilations apart from textbooks. Under a separate exemption section, the United States allows the classroom use of audiovisual material and performances if such use is limited to the students of a specific class. The United Kingdom has similar permissions and restrictions. Greece allows parents to attend the performance. France again relies on licensing. The United States also allows public performances of a nondramatic literary or musical work provided the performance is not transmitted electronically, there is no admission charge, or the money earned is used exclusively for educational, religious, or charitable purposes.

\section{Conclusion}

There needs to be negotiated compromises between the EU and U.S regarding copyright. One important first step would be recognizing that there is greater flexibility inherent in the three-step-test than has been recognised in national copyright laws. Defining "special cases" too narrowly has inhibited European nations in addressing the evolving use of the Internet by educators, and impeded having important digital material freely available for use in both face-to-face and online classrooms. Moving away from the concept of "special cases" and looking instead at the general purpose and character of using a copyrighted work may help to make this flexibility more apparent. Such melding of fair use and the three-step-test would encourage a more open-ended approach to copyright exemptions and expand access to important educational resources. The court-centric case-by-case review used in the fair use system of the United States may be too extreme for many European nations, who prefer clearer standards. General guidelines, rather than specific cases, would preserve the desired flexibility for applying the test. These guidelines should be negotiated on an international basis and uniformly applied to achieve greater consistency in the exemptions needed for accessing educational resources. 


\section{References}

Agreement on Trade-Related Aspects of Intellectual Property Rights." WTOintellecual Property (TRIPS) agreement text. World Trade Organization (WTO), n.d. Web. 16 June 2016. https://www.wto.org/english/tratop_e/trips_e/t_agm0_e.htm.

Beijing Treaty on Audiovisual Performances." WIPO-Administered Treaties. World Intellectual Property Organization, n.d. Web. 16 June 2016. http://www.wipo.int/ wipolex/en/treaties/text.jsp?file_id=295838.

Berne Convention for the Protection of Literary and Artistic Works: Stockholm Act (1967)." Berne Convention for the Protection of Literary and Artistic Works. World Intellectual Property Organization (WIPO), n.d. Web. 16 June 2016. http://www.wipo.int/wipolex/en/details.jsp?id=12801.

Berne Convention for the Protection of Literary and Artistic Works 1979." WIPOAdministered Treaties. World Intellectual Property Organization (WIPO), n.d. Web. 16 June 2016. http://www.wipo.int/treaties/en/text.jsp?file_id=283698.

Code de la propriété intellectuelle (version consolidée au 25 avril 2016). France: Intellectual Property Code (consolidated to April 25, 2016). World Intellectual Property Organization (WIPO), n.d. Web. 16 June 2016. http://www.wipo.int/wi polex/en/text.jsp?file_id=403397.

Cohen, J. E. (2007). "Creativity and Culture in Copyright Theory" in Davis Law Review, 40: 1151-205.

Congleton, R. J. and Sh. Yang (2011). "A Comparative Study of Academic Digital Copyright in the United States and Europe." Lecture Notes in Computer Science: Vol. 6966: 216-226., Belin: Springer:

Convention concernant La Creation d'une Union Internationale pour la Protection Des Oeuvres Litteraraires et artistiques 1886. WIPO-Administered Treaties. World Intellectual Property Organization, n.d. Web. 16 June 2016. http://www.wipo.int/ wipolex/en/treaties/text.jsp?file_id=278701.

Geller, P.E. (2000). "Copyright History and the Future: What's Culture Got to Do with It?" in Journal of the Copyright Society of the USA, vol. 47:209-264.

2014 No. 2356 Copyright Rights in Performances (Quotation and Parody) Regulations 2014. National Archives of the United Kingdom, n.d. Web. 16 June 2016. http://www.legislation.gov.uk/uksi/2014/2356/pdfs/uksi_20142356_en.pdf.

Copyright Designs and Patents Act 1988 (Chapter 48). United Kingdom: Copyright Designs and Patents Act (1988) (Chapter 48). World Intellectual Property Organization (WIPO), n.d. Web. 16 June 2016. http://www.wipo.int/wipolex/en/ text.jsp?file_id=309032.

Copyright Law of the United States. U.S. Copyright Law, Title 17 - cic92. United States Government, n.d. Web. 16 June 2016. http://www.copyright.gov/title17/ circ92.pdf.

The EU copyright legislation. Digital Single Market. European Commission, n.d. Web. 16 June 2016. https://ec.europa.eu/digital-single-market/en/eu-copyrightlegislation.

Fair Dealing. Guidance - Exception to Copyright, 18 Nov. 2014, www.gov.uk/guidance/ exceptions-to-copyright.

Greece - Law No. 2121/1993 on Copyright, Related Rights and Cultural Matters (as amended up to Law No. 4281/2014). World Intellectual Property Organization (WIPO), n.d. Web. 16 June 2016. http://www.wipo.int/wipolex/en/text.jsp?file $\mathrm{id}=367777$. 
Hilty, R. and S. Nerisson (2012). "Balance of Copyright" General Reports of the XVIIIth Congresss of the International Academy of Comparative Law/Rapports Generaux du XVIIIeme Congres De l'Academie Internationale de Droit Compare, edited by Karen B. Brown and David V. Snyder; 2:355-392. Dordrecht: Springer..

WIPO Copyright Treaty 1996. WIPO-Administered Treaties. World Intellectual Property Organization, n.d. Web. 16 June 2016. http://www.wipo.int/wipolex/en/ treaties/text.jsp?file_id=295166.

WIPO Performances and Phonograms Treaty. WIPO-Administered Treaties. World Intellectual Property Organization (WIPO), n.d. Web. 16 June 2016. http://www. wipo.int/wipolex/en/treaties/text.jsp?file_id=295477.

WIPO Performances and Phonograms Treaty (WPPT). WIPO-Administered Treaties. World Intellectual Property Organization (WIPO), n.d. Web. 16 June 2016. http://www.wipo.int/treaties/en/text.jsp?file_id=295578.

Xalabarder, R. (2004). "Copyright Exceptions for Teaching Purposes in Europe", in 3 Working Paper Series, Universat Oberta de Catalunya. journals.uoc.edu/index. php/in3-working-paper-series/article/view/n4-xalabarder.

Xalabarder, R. (2009). Study on Copyright Limitations and Exceptions for Educational Activities in North America, Europe, Caucasus, Central Asia, and Israel. Geneva: World Intellectual Property Organization.

\section{Cases}

Basic Books, Inc. v. Kinko's Graphics Corp., 758 F. Supp. 1522 - Dist. Court, SD New York 1991

Cambridge University Press v. Patton, 769 F.3d 1232 (11th Cir. Ga. 2014)

Folsom v. Marsh. 9 F. Cas. 342, No. 4,901 (C.C.D. Mass. 1841). http://copyright.gov/ fair-use/summaries/folsom-marsh-ccmass1841.pdf 
